\title{
A Combinatorial Approach to Corrosion Inhibition of Alloy
}

\author{
Renita D'Souza', Amit Chattree², Susai Rajendran³
}

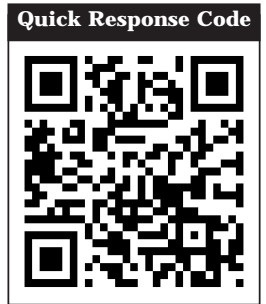

doi: $10.5866 / 2017.9 .10015$

${ }^{1}$ Research Scholar

Department of Chemistry, SHUATS,

Allahabad, 211007, UP, India.

${ }^{2}$ Associate Professor \& Head

Department of Chemistry, SHUATS,

Allahabad, 211007, UP, India.

${ }^{3}$ Professor

Corrosion Research Centre, Research Director,

Department of Chemistry,

St Antony's college of Arts and Science for women,

AmalaAnnai Nagar, Thamaraipadi (Post),

Dindigul - 624 005, INDIA.

\section{Article Info:}

Received: J anuary 9, 2017

Review Completed: February 8, 2017

Accepted: March 10, 2017

Available Online: March, 2017 (www.nacd.in)

(c) NAD, 2017 - All rights reserved

Email for correspondence:

renitavinaya@yahoo.com

\section{INTRODUCTION}

Fixed and removable prostheses are manufactured using metal alloys. It is not only important to know the physical and mechanical properties of these materials but also their biocompatibility and their resistance to corrosion. In the oral cavity, the saliva being the most corrosive agent, these structures are exposed to a chemically adverse environment.

\begin{abstract}
:
Background: Toregulate the growth of teeth peopleareimplanted with orthodontic wires made of different materials. They clean their teeth with different types of pastes. During this process the materials may undergo corrosion. Themain objective of the present study is to evaluate corrosion resistance of 22ct gold in artificial saliva in the absence and presence of an aqueous solutions of five toothpastes namely Vicco, Dant Kanti, Sparkle Fresh, Emoform and Colgate Visible White
\end{abstract}

Materials and Methods: The corrosion parameters such as corrosion potential (Ecorr), corrosion current (Icorr), linear polarization resistance (LPR), charge transfer resistance (Rct) and double layer capacitance ( $\mathrm{Cdl}$ ) have been measured by electrochemical studies. The surface morphol ogy of the protective film has been analysed with the help of UV-Visible absorption spectra, fluorescence spectra, FTIR, SEM and EDX.

Results: Among the toothpastes studied Sparkle Fresh offers better corrosion resistance to 22ct gold. For this system, LPR= 9177478 ohm cm2; Icorr = 2.701x 10-8 A/cm2; Rct $=14470 \mathrm{ohm}$ $\mathrm{cm} 2 ; \mathrm{Cdl}=3.5245 \times 10-10$ and impedance $=4.467 \mathrm{log} Z / \mathrm{ohm}$. The high corrosion resistance offered by the Sparkle Fresh toothpaste is due to formation of a compact, stable, protective film on 22ct gold in presence of Sparkle Fresh toothpaste. The active principles of the ingredients of the toothpaste have co-ordinated with the gold ions on the metal surface through their polar atoms

Conclusions: People implanted with orthodontic wires made of $22 \mathrm{ct}$ gold need not hesitate to dean their teeth with these toothpastes.

Key words: I mpedance, Ingredients, Polarization. 
released during their corrosion. ${ }^{2}$ Through corrosion process, metal ions are released from dental alloys in oral cavity even though the protective oxide film exists on the metal surface.

\section{Use of Gold in Dentistry}

Gold has traditionally found use because of its good resistance to oxidative corrosion. Gold itself is considered chemically inert and biologically compatible with the body. If longevity, functionality, aesthetics, and biocompatibility, together with ease of manufactureare consider ed as the most important requirements, the optimum material for dental restorations is still a well-approved high gold alloy. Even at much higher expense, gold is used in dentistry because of its superior performance and aesthetic appeal. Gold alloys are used for fillings, crowns, bridges, and orthodontic appliances. Gold is used in dentistry because it is chemically inert, non allergenic, and easy for the dentist to work. Corrosion of noble alloys may be clinically visible if it is severe, but more often, the release of elements continues for months or years at low levels and is not visible to the eyes. ${ }^{3}$ Gold-based alloys are referred to as noble alloys, based upon their electrochemical properties. The corrosion resistance of the alloys is due to the high thermodynamic stability of the gold in the alloys. ${ }^{4}$

The oral cavity provides a harsh environment for the orthodontic appliance of any kind. ${ }^{5}$ Several types of corrosion can take place through 1 of 2 mechanisms. Metal ions can be deposited directly into the saliva, or the protective surface film on the metal can progressively dissolve. ${ }^{6}$ Corrosion of orthodontic appliances has been thoroughly studied. ${ }^{7-12}$ There are several consequences of corrosion in orthodontics.

Orthodontic wires are recommended by the dentists to regulatethearrangement of teeth. People having these orthodontic wires have to brush their teeth daily. The toothpaste that they use may corrode the orthodontic wires in the oral environment. Hence there is a need to investigate the influence of various tooth pastes on the corrosion resistance of orthodontic wires made of many metals and alloys. The following work was undertaken to study the corrosion behaviour of 22ct gold in artificial saliva, in the absence and presence of a toothpaste sparkle fresh.

\section{Materials and Methods}

\section{Materials}

The metal specimen chosen for the present study was 22ct gold and the toothpaste was Sparkle Fresh. The composition of the toothpaste is given below:

\section{Composition of Sparkle Fresh}

Sodium Monofluorophosphate (Active Ingredients), Calcium carbonate, Carboxy methyl cellulose, Glycerine, Hydrated silica, Sodium benzoate, Sodium lauryl sulfate, Sodium saccharin, sorbitol, Tetra sodium pyrophosphate and water (I nactive ingredients).

\section{Fusayama Artificial Saliva}

Fusayama was used as an electrolyte medium (Table 1). ${ }^{13}$ F usayama artificial saliva solution constituents cl osely resemblethose of natural saliva. During the study, the artificial saliva solution temperature was maintained at room temperature of $25 \%$ C. ${ }^{14}$

\section{Methods}

\section{Potentiodynamic Polarization}

Polarization studies were carried out in a $\mathrm{CHI}$ Electrochemical workstation with impedance, Model 660A. A three el ectrode cell assembly was used. The working el ectrode was one of the metals. A saturated cal omel el ectrode (SCE) was the reference el ectrode and platinum was the counter electrode. From the polarization study, corrosion parameters such as corrosion potential $\left(\mathrm{E}_{\text {corr }}\right)$, corrosion current $\left(\mathrm{I}_{\text {corr }}\right)$, linear polarization resistance (LPR) and Tefel slopes (anodic $=b_{a}$ and cathodic $=b_{c}$ ) were calculated.

\section{AC Impedance Spectra}

The instrument used for polarization study was used to record AC impedance spectra also. The cell set up was also the same. The real part ( $\left.Z^{\prime}\right)$ and imaginary part ( $\left.Z^{\prime \prime}\right)$ of the cell impedance were measured in ohms at various frequencies. Values of the charge transfer resistance $\left(R_{t}\right)$ and the double layer capacitance $\left(\mathrm{C}_{\mathrm{dl}}\right)$ were cal culated from $\mathrm{N}$ yquist plots. I mpedance log (Z/ohm) was calculated from Bode plots. During AC impedance spectra were recorded the scan rate (V/s) was 0.005 ; Hold time at $\mathrm{Ef}(\mathrm{s})$ was zero and quite time (s) was 2 . The value of charge transfer resistance $\left(R_{t}\right)$ and double layer capacitance $\left(\mathrm{C}_{\mathrm{dl}}\right)$ were calculated from Nyquist plot. 
$\mathbf{R}_{\mathrm{t}}=\left(\mathbf{R}_{\mathrm{s}}+\mathbf{R}_{\mathrm{t}}\right)-\mathbf{R}_{\mathrm{s}}$

Where $R_{s}=$ Solution resistance, $R_{t}=$ Charge transfer resistance

1

Cdl $=\quad-\frac{1}{2 \times 3.14 \times R_{t} X f_{\text {max }}}$

Where $\mathrm{f}_{\max }=$ frequency at maximum imaginary impedance.

\section{Surface Characterization Studies}

The thin wire metal specimen immersed in an inhibitor system, for a period of one day. The specimen was taken out, dried and the nature of the film formed on the surface of the metal specimen was analysed by surface analysis techniques.

\section{Scanning Electron Microscopic Study (SEM)}

The surface morphology was examined for the thin wire metal specimen in absence and in the presence of the inhibitor system by using Tescon, Vega3, and USA computer controlled scanning el ectron microscope. The specimen immersed in the system for a period of one day was removed, rinsed with double distilled water, dried and observed in a scanning el ectron microscope to examine the surface morphology.

\section{Energy Dispersive Analysis of X-Rays (EDAX)}

SEM imaging gives the morphological data for a sample; however by using $\mathrm{x}$-ray spectroscopy in conjunction with SEM, the elemental composition can be determined. The elements present in a material are determined by an EDAX spectrum. An energy dispersive X-ray analyzer (EDAX) [Brucker, Nano, GMBH, Germany] unit attached to the SEM machine was used to carry out the elemental analysis of the metal surface.

\section{Surface Analysis by FTIR Spectra}

The FTIR spectra were recorded for the inhibitor and for the film formed on the thin wire metal specimen surface. A thin layer of inhibitor was applied on the metal surface, dried and was car efully scratched off. It was then mixed with $\mathrm{KBr}$ and made into pellets and the FTIR spectrum was recorded. The FTIR spectrum of film formed on the surface of thin wire metal specimen were recorded after immersion period of one day in artificial solution containing toothpaste SparkleF resh. The specimens were taken out of the test solutions and dried. The film formed on the surface was scratched carefully and it was thoroughly mixed with $\mathrm{KBr}$, and made into pellets. FTIR spectrum of the powder $(\mathrm{KBr}$ pellet) was recorded using Perkin -EImer $1600 \mathrm{FTIR}$ spectrophotometer with a resolving power of $4 \mathrm{~cm}$ 1.

\section{UV- Visible Absorption Spectra}

The possibility of the formation of metal inhibitor complex in solution was examined by recording their UV-Visibleabsorption spectra for the blank, the inhibitor and the best system solution using Analytic J ena Specord S-100, UV -Visible spectrometer.

\section{Fluorescence Spectroscopy}

Fluorescence spectra of solutions, blank, the inhibitor and the best system were recorded by Using J asco- 6300 spectroflurometer.

\section{Results and Discussion}

\section{Analysis of Potentiodynamic Polarization Curves}

The corrosion parameters namely, corrosion potentiall $\left(E_{\text {corr }}\right)$, Tafel slopes $\left(b_{c}=\right.$ cathodic; $b_{a}=$ anodic), linear polarization resistance (LPR) and corrosion current $\left(\mathrm{I}_{\text {corr }}\right)$ of 22ct gold immersed in artificial saliva (AS) in the absence and presence of tooth paste are given in Table 2 and the potentio dynamic polarization curves are shown in Figure 1.

This observes that when 22ct gold immersed in AS, the corrosion potential is $-061 \mathrm{mV}$ vs SCE. The linear polarization resistance value is $2589619 \mathrm{ohm}$ $\mathrm{cm}^{2}$. The corrosion current is $14.18 \times 10^{-9} \mathrm{~A} / \mathrm{cm}^{2}$. When 22ct gold is immersed in aqueous solution of (1\%) SparkleF resh, the corrosion potential is shifted to cathodic side $(-093 \mathrm{mV}$ vs SCE ). The linear polarization resistance (LPR) value increases from $2589619 \mathrm{ohm} \mathrm{cm}^{2}$ to $5280874 \mathrm{ohm} \mathrm{cm}^{2}$. The corrosion current decreases from $14.18 \times 10^{-9} \mathrm{~A} / \mathrm{cm}^{2}$ to 6.161 $\times 10^{-9} \mathrm{~A} / \mathrm{cm}^{2}$. These observations indicate that the cathodic reaction is controlled predominantly. A protective film is formed on the metal surface. Hence linear polarization resistance (LPR) value increases and corrosion current $\left(I_{\text {corr }}\right)$ decreases. The protective film may probably consist of complexes formed between gold ion and the active principles of the ingredients of tooth pastes.

When 22ct gold is immersed in aqueous solutions consisting of AS and the $1 \%$ pastes solutions, the corrosion potential is shifted to the 
anodic side (-046 mV vs SCE). The shift is within 50 $\mathrm{mV}$ vs SCE. Hence it is inferred that, both anodic and cathodic reactions are controlled to an equal extent i.e. there is mixed type corrosion inhibition. Further, the linear polarization resistance (LPR) value increases from $2589619 \mathrm{ohm} \mathrm{cm}{ }^{2}$ to 9177478 ohm $\mathrm{cm}^{2}$. Corrosion current decreases from $14.18 \mathrm{x}$ $10^{-9} \mathrm{~A} / \mathrm{cm}^{2}$ to $2.701 \times 10^{-9}$. These observations indicate that the corrosion resistance of 22ct gold increases when it is immersed in AS containing aqueous solutions of the tooth paste Sparkle Fresh.

\section{Analysis of AC Impedance Spectra}

The AC impedance spectra of 22ct gold immersed in various test solutions are shown in fig 2, 3, 4 and 5. The Nyquist plots are shown in fig 2 . The Bode plots are shown in figure 3, 4 and 5. The corrosion parameters derived from these plots are shown in table 3.

When 22ct gold is immersed in AS, the charge transfer resistance $\left(R_{t}\right)$ value is $2164 \mathrm{ohm} \mathrm{cm}{ }^{2}$, the double layer capacitance $\left(C_{d l}\right)$ value is $23.567 \times 10^{-10}$ $\mathrm{F} / \mathrm{cm}^{2}$ and the impedance (log $\mathrm{z} / \mathrm{ohm}$ ) value is 4.236 . When 22ct gold is immersed in aqueous solutions of (1\%) toothpaste Sparkle F resh, the charge transfer resistance $\left(R_{t}\right)$ value increases from $2164 \mathrm{ohm} \mathrm{cm}{ }^{2}$

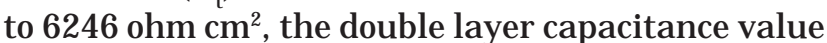
$\left(C_{d I}\right)$ value decreases from $23.567 \times 10^{-10}$ to $8.1652 \times$ $10^{-10} \mathrm{~F} / \mathrm{cm}^{2}$ and the impedance value (log $\mathrm{z} / \mathrm{ohm}$ ) increases from 4.236 to 4.314 . These observations indicate that, a protective film is formed on the metal surface when 22ct gold is immersed in aqueous solutions of tooth paste Sparkle Fresh. The protective film prevents the transfer of electrons from the metal surface to the bulk of the solutions. Hence corrosion resistance increases and the rate of corrosion decreases. The protective film probably consists of gold ion and the active principle of the ingredients of the tooth paste.

When 22ct gold is immersed in AS containing an aqueous solution of Sparkle Fresh, the charge transfer resistance $\left(R_{t}\right)$ value increases from 2164 ohm $\mathrm{cm}^{2}$ to $14470 \mathrm{ohm} \mathrm{cm}^{2}$, the double layer capacitance $\left(\mathrm{C}_{d_{1}}\right)$ value decreases from $23.567 \times 10^{-}$ 10 to $3.5245 \times 10^{-10}$, the impedance (logz/ohm) value increases from 4.236 to 4.467 . It inferred that, in presence of AS containing Sparkle Fresh, the corrosion resistance of 22ct gold increases.

\section{SEM Analysis of Metal Surface}

The SEM images for 22ct gold in the absence and in the presence of the inhibitor system is shown in Figure 6 ( $a$ and $b)$. Surface is found to be very smooth only for pure polished 22ct gold. But for the inhibitor system, surface has become rough due to the presence of film deposited on the metal surface. This protective film is due to the deposition of active principles of the ingredients present in the toothpaste. This protective film prevents the corrosion of 22ct gold in presence of artificial saliva and the toothpaste.

\section{Energy Dispersive Analysis of X -Rays (EDAX)}

The EDAX spectra are shown in figure 7 ( $a$ and b). It is seen from the EDAX spectra that Au and $\mathrm{Cu}$ are present in both absence and presence of the inhibitor (Table 4 and 5). But the weight percentage of gold and copper has changed after immersion in the artificial saliva containing sparkle fresh toothpaste.

In the case of bare 22ct gold, because of the presence of the copper, the metal would have undergone atmospheric corrosion due to leaching out of copper and copper oxide would have formed on the metal surface. This layer would have decreased the intensity of gold (Figure $7 b$ ).

When the electrode is immersed in the environment consisting of saliva and the toothpaste, the active principles of the ingredients of the toothpaste would have formed a protective film on the metal surface, thus preventing the corrosion of $22 c t$ gold. This results in theincrease in theintensity of gold. The increase in corrosion resistance is supported by electrochemical studies.

\section{Analysis of FTIR Spectra}

The FTIR ( $\mathrm{KBr}$ ) spectrum of pure toothpaste sparkle fresh is shown in figure8 .Analysis of the structures of these compounds reveals that the active principles of the ingredients of toothpaste sparkle fresh contain functional groups like $\mathrm{OH}$, $\mathrm{C}=\mathrm{O}, \mathrm{S}, \mathrm{N}$ and an aromatic ring. The peak appears at $3379 \mathrm{~cm}^{-1}$ is due to $\mathrm{O}-\mathrm{H}$ stretching frequency. $2921.59 \mathrm{~cm}^{-1}$ and $2852.44 \mathrm{~cm}^{-1}$ peaks are due to $\mathrm{C}-\mathrm{H}$ stretching frequency. S-H stretching frequency was observed at $2512.45 \mathrm{~cm}^{-1} .1796 .75 \mathrm{~cm}^{-1}$ peak is due to $C=O$ stretching and $1084 \mathrm{~cm}^{-1}$ and $1046 \mathrm{~cm}^{-1}$ peaks are due to $\mathrm{P}-\mathrm{O}$ stretching. $1242.14 \mathrm{~cm}^{-1}$ peak is of $\mathrm{P}=\mathrm{O}$ stretching and $1084 \mathrm{~cm}^{-1}$ peak is of C-N stretching. Peak at $1459.83 \mathrm{~cm}^{-1}$ indicate the presence of aromatic ring in the compounds present in the toothpaste. 
The FTIR spectrum of the film formed on the metal surface after immersion in artificial saliva containing toothpaste sparkle fresh is shown in figure 9. A shift is observed in the peak due to $\mathrm{O}-\mathrm{H}$ stretching frequency from $3379 \mathrm{~cm}^{-1}$ to $3363.10 \mathrm{~cm}^{-}$ ${ }^{1}$. Peak due to $\mathrm{C}-\mathrm{H}$ stretching frequency has shifted from $2852.44 \mathrm{~cm}^{-1}$ to $2875.43 \mathrm{~cm}^{-1}$.. The peaks at $1796.75 \mathrm{~cm}^{-1}$ for $\mathrm{C}=\mathrm{O}$ stretching frequency, 2512.45 $\mathrm{cm}^{-1}$ for S-H stretching frequency and $1242.14 \mathrm{~cm}^{-}$ 1peak for $\mathrm{P}=\mathrm{O}$ stretching frequency have disappeared as sulphur atom of $\mathrm{S}-\mathrm{H}$ group and oxygen atom of $\mathrm{C}=\mathrm{O}$ and $\mathrm{PO}$ groups having lone pair of electrons present in toothpaste sparkle fresh has co-ordinated strongly to gold ion and formed a complex. Peaks due to P-O stretching frequency have shifted from $1084 \mathrm{~cm}^{-1}$ to $1080.81 \mathrm{~cm}^{-1}$ and $1046 \mathrm{~cm}^{-}$ ${ }^{1}$ to $1020.51 \mathrm{~cm}^{-1}$. Peak for C-N stretching has shifted from $1084 \mathrm{~cm}^{-1}$ to $1080.81 \mathrm{~cm}^{-1}$. A shift was also observed in frequency due to aromatic ring from $1459.83 \mathrm{~cm}^{-1}$ to $1430.65 \mathrm{~cm}^{-1}$.

This result suggests that the active principles present in ingredients of toothpaste sparkle fresh have coordinated with the metal through oxygen atom of $\mathrm{OH}$ group, $\mathrm{C}=\mathrm{O}$ group and $\mathrm{PO}$ group and sulphur atom of S-H group and nitrogen atom of C$\mathrm{N}$ group forming a protective film which prevents the corrosion of 22ct gold. Compounds containing nitrogen, oxygen and sulphur can provide excellent corrosion protection efficiency compared with compounds containing either nitrogen or sulphur or oxygen. ${ }^{15}$ Synergistic effect of corrosion inhibition is observed.

\section{Analysis of UV-Visible Absorption Spectra of Solutions}

The UV- visible absorption spectrum is used to confirm the protective film formed on the metal surface. The UV- visible absorption spectrum of artificial saliva is shown in Figure 10. Peaks appear at $352 \mathrm{~nm}, 480 \mathrm{~nm}$ and $660 \mathrm{~nm}$. The UV- visible absorption spectrum of toothpaste solution is shown in Figure 11. A peak appears at $380 \mathrm{~nm}$. The UVvisible absorption spectrum of the solution of AS toothpaste system wherein 22 ct gold has been immersed for one day is shown in Figure 12. A peak appears at $380 \mathrm{~nm}$. There is no shift in the position of ë max of the toothpaste system. This indicates that gold has not undergone corrosion in presence of saliva and toothpaste system. Had there been corrosion, there would have been shift in the position of ë max. The increase in intensity at $380 \mathrm{~nm}$ may be attributed to the fact that there is no electronic transition because of co-ordination of the active principles of the ingredients of the toothpaste with 22ct gold.

\section{Analysis of Fluorescence Spectroscopy}

Fluorescence spectrum is used to detect the presence of metal- inhibitor complex formed on the surface of $22 \mathrm{ct}$ gold alloy. The fluorescence spectrum ( $\ddot{e}_{\mathrm{ex}}=300 \mathrm{~nm}$ ) of artificial saliva is shown in figure 13. A peak appears at $378.5 \mathrm{~nm}$. The fluorescence spectrum ( $\ddot{e}_{\mathrm{ex}}=300 \mathrm{~nm}$.) of an aqueous solution of sparkle fresh toothpaste is shown in figure 14. Emission takes place at $381.5 \mathrm{~nm}$. 22ct gold was immersed in an aqueous solution containing artificial saliva and the toothpaste sparkle fresh. A solution was obtained. The fluorescence spectrum ( $\ddot{\mathrm{e}}_{\mathrm{ex}}=300 \mathrm{~nm}$ ) of this solution is shown in figure 15. A peak appears at $385.5 \mathrm{~nm}$. The shift in $\ddot{e}_{\max }$ is not substantial. It is very cl ose to that of toothpaste only.

This indicates that 22ctgold has not undergone substantial corrosion in presence of AS and toothpaste. However a small hump (shoulder) appears around $460 \mathrm{~nm}$. This may be due to the release of some Cuions in this system. This indicates there is slight corrosion of 22ct gold in this medium.

\section{CONCLUSION}

The corrosion resistance of $22 \mathrm{ct}$ gold in artificial saliva in the absence and the presence of toothpaste Sparkle Fresh has been evaluated by electrochemical studies such as polarization and AC impedance spectra and surface characterization studies such as SEM, EDAX, FTIR, UV-Visible absorption and fluorescence spectra. It is observed that the corrosion resistance of 22ct gold is more in the presence of toothpaste than in the presence of artificial saliva only. In the presence of artificial saliva and toothpaste the corrosion resistance still increases. This is due to the fact that the active principles of the ingredients of the toothpaste would have coordinated with the metal ion through their polar groups such as oxygen, nitrogen and sulphur forming a protective layer on the surface of the metal. The corrosion inhibition is enhanced due to the combinatorial approach of the compounds present in the toothpaste thus exhibiting the synergistic effect. The corrosion resistance increases in the order: AS ttoothpaste > toothpaste >AS. The implication of this study is that people who have been implanted with orthodontic wires made of 18ct gold need not hesitate to clean their teeth with Sparkle Fresh toothpaste. 
Table 1: Chemical composition of artificial saliva (F usayama Meyer)

\begin{tabular}{|c|c|}
\hline Content & Quantity gL-1 \\
\hline $\mathrm{KCl}$ & 0.4 \\
\hline $\mathrm{NaCl}$ & 0.4 \\
\hline $\mathrm{CaCl}_{2} \cdot 2 \mathrm{H}_{2} \mathrm{O}$ & 0.906 \\
\hline $\mathrm{NaH}_{2} \mathrm{PO}_{4} 2 \mathrm{H}_{2} \mathrm{O}$ & 0.690 \\
\hline $\mathrm{Na}_{2} \mathrm{~S} .9 \mathrm{H}_{2} \mathrm{O}$ & 0.005 \\
\hline Urea & 1 \\
\hline
\end{tabular}

Table 2: Corrosion parameters of 22ct gold immersed in various test solutions obtained from polarization study

\begin{tabular}{|c|c|c|c|c|c|}
\hline System & $E_{\text {corr }} m V v s$ SCE & $b_{c} m V / d e c a d e$ & $b_{a} m V /$ decade & LPROhm $\mathrm{cm}^{2}$ & $I_{\text {corr }} \mathbf{A} / \mathrm{cm}^{2}$ \\
\hline AS & -061 & 099 & 563 & 2589619 & $14.18 \times 10^{-9}$ \\
\hline Sparkle Fresh & -093 & 105 & 255 & 5280874 & $6.161 \times 10^{-8}$ \\
\hline AS + Sparkle Fresh & -046 & 118 & 110 & 9177478 & $2.701 \times 10^{-8}$ \\
\hline
\end{tabular}

Table 3: Corrosion parameters of 22ct gold immersed in various test solutions obtained from AC impedance spectra.

\begin{tabular}{lccc} 
System & \multicolumn{2}{c}{ Nyquist plot } & \multicolumn{2}{c}{$\begin{array}{c}\text { Bode plot } \\
\mathbf{R}_{\mathbf{t}} \text { Ohm } \mathbf{~ c m}^{2}\end{array}$} & $\mathbf{C}_{\mathrm{dl}} \mathbf{F} / \mathbf{c m}^{2}$ & Impedance valuelog z/ohm \\
\hline AS & 2164 & $23.567 \times 10^{-10}$ & 4.236 \\
\hline Sparkle F & 6246 & $8.1652 \times 10^{-10}$ & 4.314 \\
\hline AS + Sparkle F & 14470 & $3.5245 \times 10^{-10}$ & 4.467 \\
\hline
\end{tabular}

Table 4: Spectrum of 22ct gold

\begin{tabular}{lrrrrrr} 
& AN & Series & $\begin{array}{r}\text { Unn. C } \\
\text { (Wt \%) }\end{array}$ & $\begin{array}{r}\text { Norm. C } \\
\text { (Wt \%) }\end{array}$ & $\begin{array}{r}\text { Atom C } \\
\text { (Wt \%) }\end{array}$ & $\begin{array}{r}\text { Error (1Sigma) } \\
\text { (Wt \%) }\end{array}$ \\
C & 6 & K-Series & 7.45 & 6.95 & 52.91 & 1.87 \\
\hline $\mathrm{Au}$ & 79 & L-Series & 95.42 & 89.02 & 41.30 & 2.41 \\
\hline $\mathrm{Cu}$ & 29 & K-Series & 4.32 & 4.03 & 5.79 & 0.15 \\
\hline Total & & 107.19 & 100.00 & 100.00 & \\
\hline \multicolumn{7}{l}{ Table 4: Spectrum of 22ct Gold } \\
\hline
\end{tabular}

Table 5: Spectrum of 22 ct gold +AS+ Sparkle fresh toothpaste

\begin{tabular}{lrlrrrr} 
& AN & Series & $\begin{array}{r}\text { Unn. C } \\
\text { (Wt \%) }\end{array}$ & $\begin{array}{r}\text { Norm. C } \\
\text { (Wt \%) }\end{array}$ & $\begin{array}{r}\text { Atom C } \\
\text { (Wt \%) }\end{array}$ & $\begin{array}{r}\text { Error (1Sigma) } \\
\text { (Wt \%) }\end{array}$ \\
C & 6 & K-Series & 6.81 & 6.55 & 51.96 & 2.56 \\
\hline $\mathrm{Au}$ & 79 & L-Series & 94.26 & 90.64 & 43.84 & 2.51 \\
\hline $\mathrm{Cu}$ & 29 & K-Series & 2.92 & 2.81 & 4.21 & 0.15 \\
\hline Total & & & 103.99 & 100.00 & 100.00 &
\end{tabular}

Table 5: Spectrum of 22ct Gold +AS+Sparkle Fresh toothpaste 


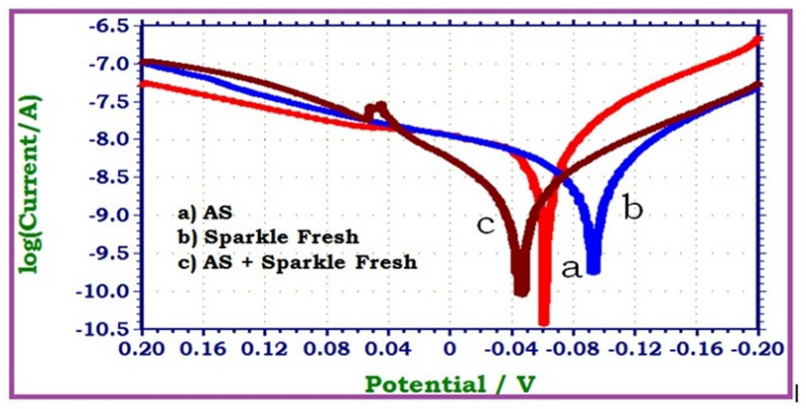

Fig 1: Polarisation curves of $22 \mathrm{ct}$ gold immersed in Artificial Saliva (AS) in the absence and presence of toothpaste Sparkle Fresh

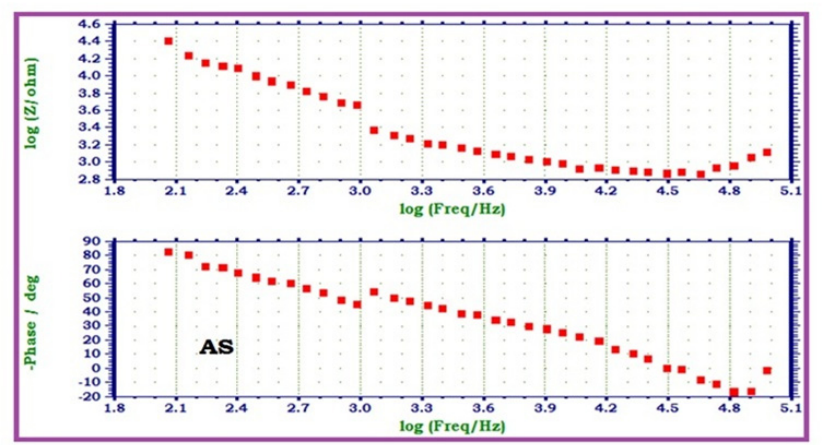

Fig 3:AC impedance spectra of 22ct gold immersed in Artificial Saliva(AS) (Bode Plots)

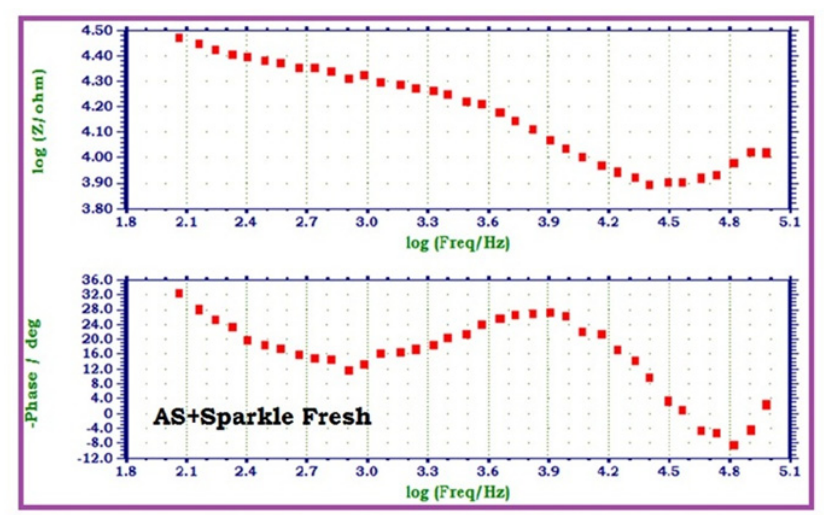

Fig 5: AC impedance spectra of 22ct gold immersed in Artificial saliva(AS) in the presence of Sparkle Fresh (1\%) (Bode Plots)
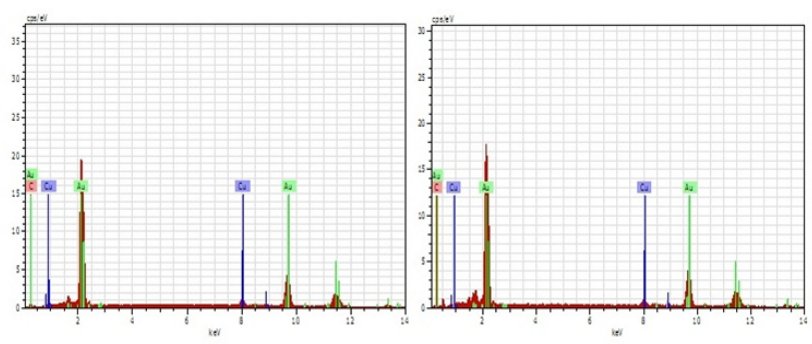

Fig 7. EDAX spectra of

(a) Polished 22ct gold

(b)Polished 22ct gold immersed in AS containing sparkle fresh toothpaste

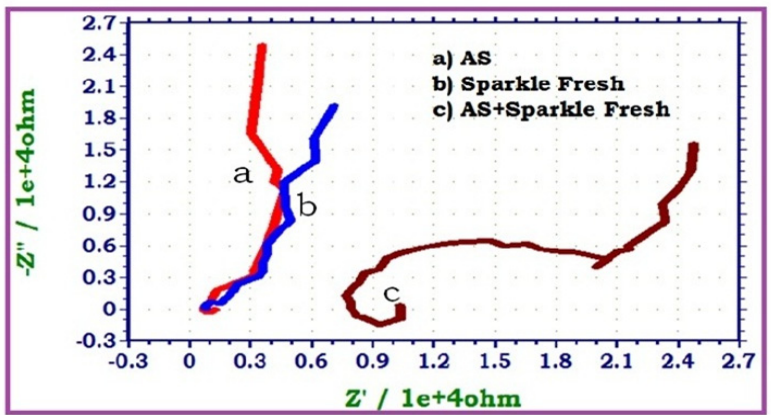

Fig 2:AC impedance spectra of $22 \mathrm{ct}$ gold immersed in Artificial Saliva (AS) in the absence and presence of tooth paste Sparkle Fresh(Nyquist Plots)

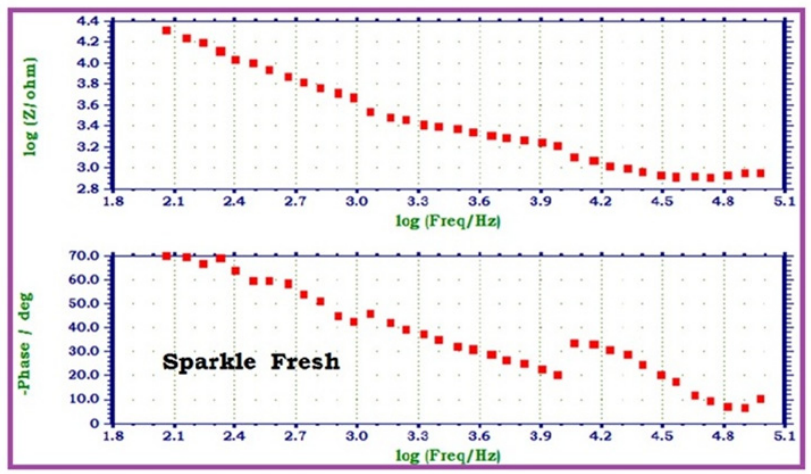

Fig 4: AC impedance spectra of 22ct gold immersed in Sparkle Fresh(1\%) (Bode Plots)

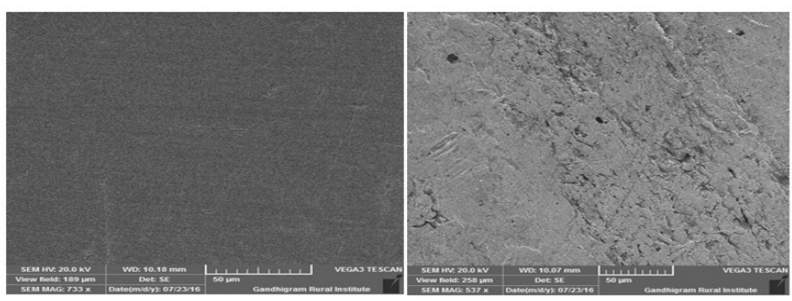

Fig 6. SEM images for

(a) Polished 22ct gold

(b)Polished 22ct gold immersed in AS containing sparkle fresh toothpaste

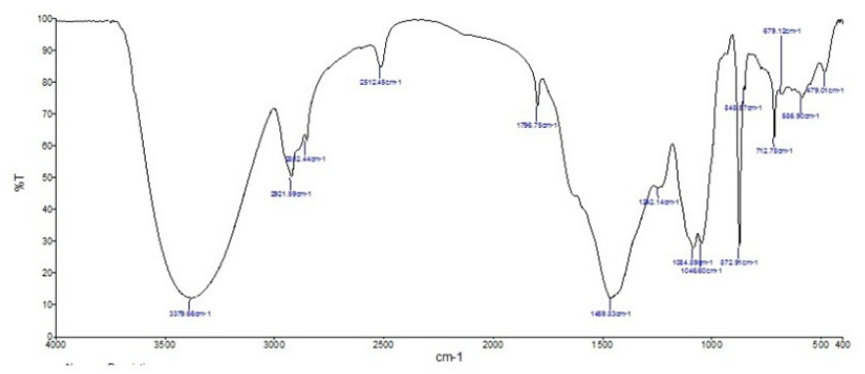

Fig 8. The FTIR ( $\mathrm{KBr}$ ) spectrum of pure toothpaste sparkle fresh 


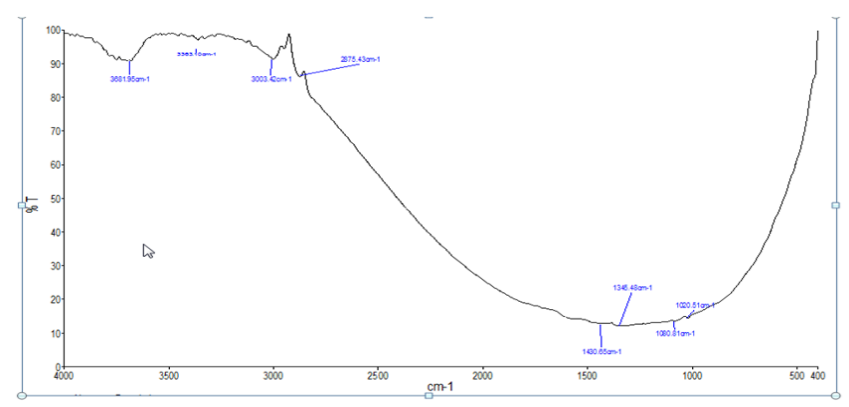

Fig 9. The FTIR spectrum of the film formed on the metal surface after immersion in artificial saliva containing toothpaste sparkle fresh

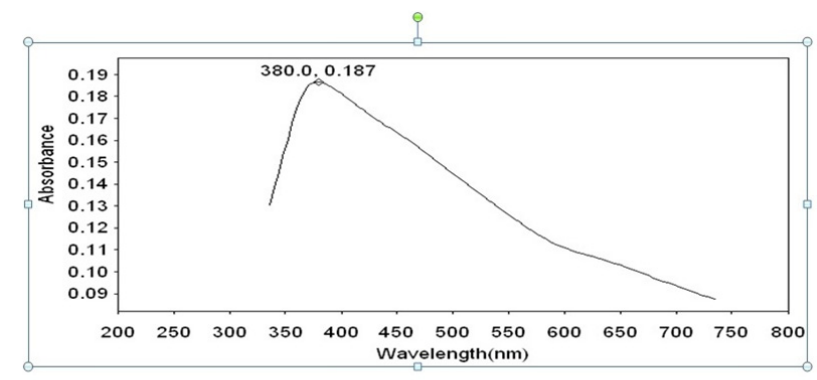

Fig 11 :UV-Visible absorption spectrum of solution containing Sparkle fresh toothpaste

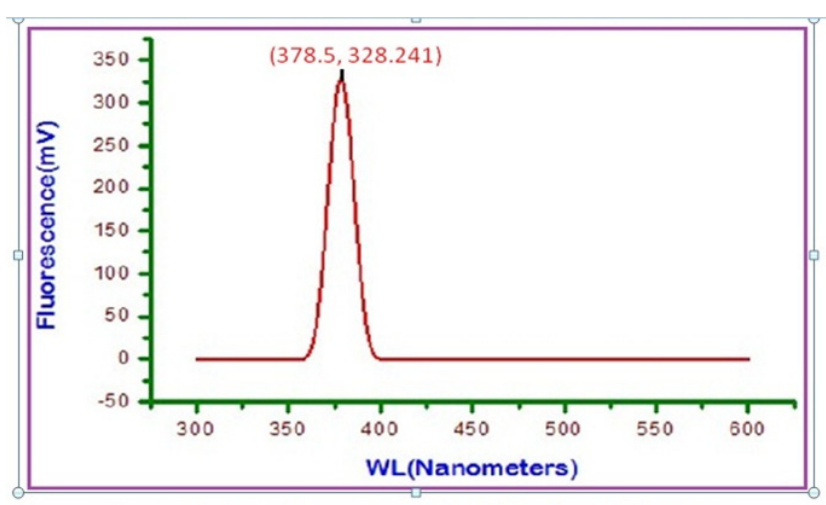

Fig 13. Fluorescence spectrum of artificial saliva(AS) solution

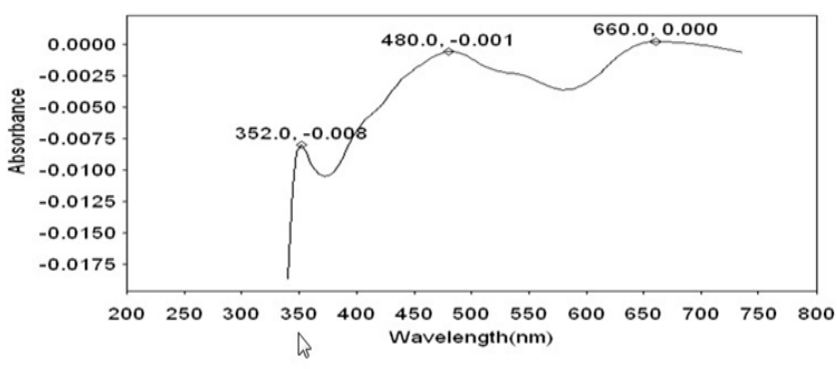

Fig 10 :UV-Visible absorption spectrum of artificial saliva|

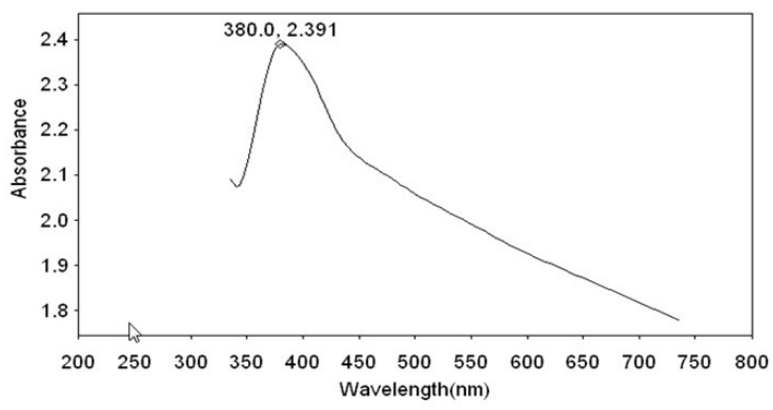

Fig 12 :UV-Visible absorption spectrun of solution containing 22ct gold + AS+ Sparkle fresh toothpaste

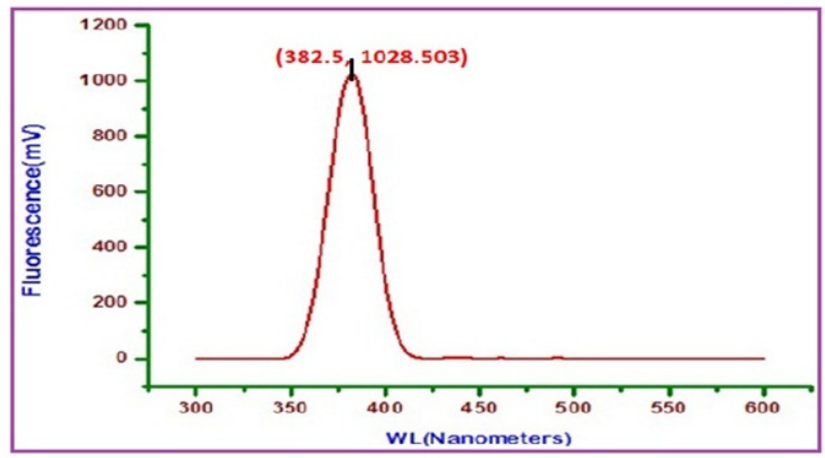

Fig 14: Fluorescence spectrum of solution containing Sparkle Fresh toothpaste

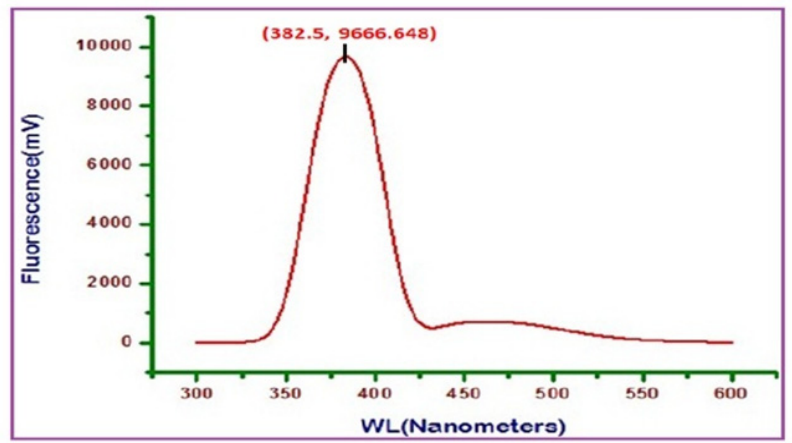

Fig 15 : Fluorescence spectrum of solution containing $22 \mathrm{ct}$ gold + AS + Sparkle Fresh toothpaste 


\section{REFERENCES}

1. Karov J, Hinberg I. Galvanic corrosion of selected dental alloys, J Oral Rehabil 2001; 28:212-9.

2. Schmalz G, Garhammer P. Biological interactions of dental cast alloys with oral tissues. Dental Materials 2002; 18:396406.

3. Wataha J C, Lockwood PE, Nelson SK, Bouillaguet S.Longterm cytotoxicity of dental casting alloys. Int J Prosthodont 1999; 12:242e8.

4. Lucas LC, Lemons JE. Biodegradation of restorative metallic systems. Adv Dent Res 1992; 6:32e7.

5. Mc Cann HC. Inorganic components of salivary secretions in Art and Science of Dental Caries Research, R. S. Harris, Ed, Academic Press, New York, NY, USA, 1968. p 55-70.

6. Von Fraunhofer J A. Corrosion of orthodontic devices. Semin Orthod 1997; 3:198-205.

7. Walker MP, White RJ, and Kula KS. Effect of fluoride prophylactic agents on the mechanical properties of nickeltitanium-based orthodontic wires. Am J Orth Dentofacial Orthopedics 2005; 127( 6):662-9.

8. Kaneko K, Yokoyama K, Moriyama K, Asaoka K, and Sakai $J$. Degradation in performance of orthodontic wirescaused by hydrogen absorption during short-term immersion in
$2.0 \%$ acidulated phosphate fluoride solution. Angle Orthodontist 2004; 74( 4):487-95.

9. Yokoyama K, Kaneko K, Ogawa T, M oriyama K, Asaoka K and Sakai J. Hydrogen embrittlement of work-hardened $\mathrm{Ni}-\mathrm{Ti}$ alloy in fluoride solutions. Biomaterials 2005; 26(1):101- 8.

10. Schiff N, Grosgogeat B, Lissac M, and Dalard F. Influence of fluoridated mouthwashes on corrosion resistance of orthodontics wires. Biomaterials 2004; 25(19):4535-42.

11. Ogawa T, Yokoyama K, Asaoka K, and Sakai J . Hydrogen absorption behavior of beta titanium alloy in acid fluoride solutions. Biomaterials 2004; 25(12):2419-25.

12. Kaneko K, Yokoyama K, Moriyama K, Asaoka K, Sakai J and Nagumo $M$. Delayed fracture of beta titaniumorthodontic wire in fluoride aqueous solutions. Biomaterials 2003; 24(12):2113-20.

13. Rajendran S, Paulraj J, Rengan P, J eyasundari J and Manivannan M. Corrosion behaviour of metals in artificial saliva in presence of spirulina powder. J Dent Oral Hyg 2009; 1(1):1-8.

14. Geis-Gerstorfer J, Sauer K H and Assler K P. I on release from $\mathrm{Ni}-\mathrm{Cr}-\mathrm{Mo}$ and $\mathrm{Co}-\mathrm{Cr}-\mathrm{Mo}$ casting alloys. Intl J Prosthodontics 1991; 4(2):152-8.

15. Sastri VS, Corrosion I nhibitors: Principles and Applications, published by Wiley, Chichester, England, 1998.

\section{Gain quick access to our journal online View our journal at www.nacd.in}

